\title{
STRATEGI PEMASARAN BALI APOLLO DIVE AND WATER SPORT UNTUK MENINGKATKAN KUNJUNGAN WISATAWAN
}

\author{
Vicky Fatahilah Sani ${ }^{1}$, Ni Putu Eka Mahadewi ${ }^{2}$, Putu Agus Wikanatha Sagita ${ }^{3}$ \\ Email: vicky.fatahilah@yahoo.com¹,eka.mahadewi23@gmail.com², aguswika@unud.ac.id³ \\ ${ }^{1,2,3}$ Program Studi Industri Perjalanan Wisata, FakultasPariwisata, UniversitasUdayana
}

\begin{abstract}
Bali Apollo Dive \& Water Sport is a company that provides various types of activities and water sports in Tanjung Benoa. Along with the development of tourism in Bali, the interest of tourists to carry out water sport activities is increasing so that many stakeholders have established a water sport tourism business which makes competition between water sport companies tight, therefore this phenomenon is the background of this research The data collection methods used in this study were observation, interviews, documentation, literature studies and the distribution of internal and external questionnaires to 150 respondents who used the Bali Apollo Dive \& Water Sport water sport tour package as well as to the Bali Apollo Dive \& Water Sport and academics. Tourism. The results of the study The results of the study using 17 internal environmental sub-indicators and 11 external environmental sub-indicators, then obtained 14 strength factors, 3 weakness factors, 8 opportunity factors and 3 threat factors. Based on the results of data processing on external internal factors/IFAS EFAS Bali Apollo Dive \& Water Sport, it is known that the total value of IFAS is 3.17 and the total value of EFAS is 2.31, indicating the position of the Bali Apollo Dive \& Water Sport water sport package is in cell VIII, namely Conglomerate Growth and Diversification Strategy. In this position, the strategy used by Bali Apollo Dive \& Water Sport in marketing water sport packages requires a growth strategy through strategic emphasis on financial synergies rather than product marketing synergies.
\end{abstract}

\begin{abstract}
Abstrak: Bali Apollo Dive \& Water Sport merupakan salah satu perusahaan yang menyediakan berbagai jenis aktivitas dan olah raga air (watersport) yang berada di di Tanjung Benoa. Seiring perkembangan pariwisata di Bali minat wisatawan untuk melakukan aktivitas water sport semakin meningakat sehingga banyak stakeholders yang mendirikan usaha pariwisata water sport yang membuat persaingan antar perusahaan water sport menjadi ketat, maka dari itu fenomena ini mampu melatar belakangi penelitian ini. Metode pengumpulan data yang digunakan dalam penelitian ini adalah observasi, wawancara, dokumentasi, studi kepustakaan serta penyebaran kuesioner internal dan eksternal kepada 150 respoden yang yang menggunakan paket wisata water sport Bali Apollo Dive \& Water Sport serta kepada pihak Bali Apollo Dive \& Water Sport dan Akademisi Pariwisata. Hasil dari penelitian Hasil penelitian menggunakan 17 sub indikator lingkungan internal dan 11 sub indikator lingkungan eksternal, maka diperoleh 14 faktor kekuatan, 3 faktor kelemahan, 8 faktor peluang dan 3 faktor ancaman. Berdasarkan hasil pengolahan data terhadap faktor internal eksternal/IFAS EFAS Bali Apollo Dive \& Water Sport diketahui total nilai IFAS adalah 3,17 dan total nilai EFAS adalah 2,31 sehingga menunjukkan posisi paket water sport Bali Apollo Dive \& Water Sport berada pada sel VIII yaitu Strategi Growth dan Diversifikasi Konglomerat. Dalam posisi ini strategi yang digunaka oleh Bali Apollo Dive \& Water Sport dalam memasarkan paket water sport memerlukan strategi pertumbuhan melalui tekanan strategi lebih pada sinergi finansial daripada sinergi pemasaran produk.
\end{abstract}

Keywords: bali apollo, marketing strategy, water sport. 


\section{PENDAHULUAN}

Bali Apollo Dive \& Water Sport merupakan perusahaan yang menyediakan paket water sport yang berdiri sejaktahun 2000 yang tetap aktif dan berkembang sampai saat ini. Bali Apollo Dive \& Water Sport, merupakan salah satu perusahaan pariwisata di bidang wisata bahari yang menawarkan jasa olah raga air yang terletak di Tanjung Benoa Bali. Bali Apollo Dive \& Water Sport memiliki banyak inovasi perihal paket wisata dan memiliki fasilitas yang sangat sangat lengkap dibandingkan perusahaan watersport lainnya yang ada di Tanjung Benoa, yang membuat perusahaan Bali Apollo Dive \& Water sport tetap bertahan dan dikenal oleh wisatawan.

Data menunjukkan bahwa jumalah wisatawan yang menggunakan jasa Bali Apollo Dive \& Watersport sejak tahun 2014 sampai 2019 mengalami pertumbuhan rata-rata $6.72 \%$. pada tahun 2017 jumlah wisatawan mengalami penurunan sebesar $7.96 \%$ yang disebabkan karena terjadinya erupsi gunung agung di Karangasem, akibatnya banyak Negara asal wisatawan mengeluarkan larangan berkunjung ke Indonesia khususnya di bali demi keamanan dan keselamatan wisatawan. Pada tahun 2018 wisatawan yang menggunakan jasa Bali Apollo Dive \& Watersport mengalami peningkatan 13.68\%. Pada tahun 2019 wisatawan yang menggunakan Bali Apollo Dive \& Water Sport mengalami peningkatan sebanyak 5.671 dengan presentase $8.16 \%$ dikarenakan kondusifnya tingkat keamanan di Bali dan meningkatnya pelayanan dan popularitas Bali Apollo Dive \& Water Sport.

Pada tahun 2020 jumlah kunjungan wisatawan sangat menurun dengan presentase $85 \%$ dikarena adanya virus corona yang tersebar di seluruh dunia. Keadaan seperti ini telah membawa dampak yang kurang menguntungkan bagi kepariwisataan di Indonesia, khususnya yang berkaitan dengan paket wisata dikarenakan kondisi tersebut berdampak langsung kepada wisatawan. Maka dari itu stakeholders harus memutar otak bagaimana cara agar wisatawan berkunjung dan menggunakan Bali Apollo Dive \& Water Sport., dibawah ini adalah data kunjungan wisatawan dibulan Agustus - November 2020, terhitung sejak Bali Apollo Dive \& Water Sport mulai bangkit sejak awal Agustus 2020 akibat pandemi Covid-19.
Berdasarkan data jumlah kunjungan wisatawan Bali Apollo Dive \& Water Sport dari bulan Agustus sampai dengan November 2021 mengalami peningkatan yang cukup signifikan. Pada bulan Agustus 2020 jumlah kunjungan wisatawan yang berkunjung berjumlah 102 dan mengalami peningkatan pada bulan September 2020 menjadi 140 dengan presentase peningkatan $37,3 \%$, dan pada bulan Oktober 2020 jumlah kunjungan wisatawan meningkat sebanyak $27,1 \%$ dengan jumlah wisatawan 178 wisatawan, di bulan November meningkat lagi sebanyak $37,6 \%$ dengan jumlah wisatawan sebanyak 245 wisatawan. Dari perkembangan jumlah kunjungan wisatawan diatas dapat dilihat bahwa strategi pemasaran yang dilakukan oleh Bali Apollo Dive \& Water Sport sudah berjalan sesuai dengan yang diinginkan oleh Bali Apollo Dive \& Water Sport.

\section{METODE}

Penelitian ini dilakukan di sebuah perusahaan wisata minat khusus Water Sport. Perusahaan itu bernama Bali Apollo Dive \& Water Sport yang berlokasi di Tanjung Benoa, Jl. Pratama No.70, Benoa, Nusa Dua, Kabupaten Badung, provinsi Bali.. Bali Apollo Dive \& Water Sport dapat ditempuh selama 35 menit dari Bandara Internasional I Gusti Ngurah Rai, 40 menit dari Kuta, dan dari pusat Kota Denpasar dapat ditempuh kurang lebih selama 1 jam perjalanan. Penelitian ini dilakukan di Bali Apollo Dive \& Water Sport dikarenakan perusahaan tersebut merupakan perusahaan yang menyediakan paket Water Sport terlengkap dan terbesar yang terdapat di Pantai Tanjung Benoa, Bali. Dalam melakukan penelitian ini, peneliti menggunakan definisi operasional variabel strategi bauran pemasaran 7P agar penelitian tidak keluar dari fokus penelitian sebenarnya sehingga menghasilkan penelitian yang sesuai dan detail. Berikut terdapat beberapa komponen variable yang terdapat dalam bauran pemasaran dalam penelitian ini.

\section{Faktor Internal}

Faktor internal dalam penelitian ini adalah segala kekuatan dan kelemahan dari Bali Apollo Dive \& Water Sport yang dapat diidentifikasikan melalui pendapat wisatawan nusantara mengenai strategi pemasaran yang dilakukan Bali Apollo Dive \& Water Sport. 
Strategi pemasaran dalam penelitian ini menggunakan bauran pemasaran (marketing $m i x)$ yang tediri dari 7P yaitu:

1. Produk (Product)

Analisis produk dalam penelitian ini adalah menganalisa kualitas produk dan jasa, variasi serta fasilitas yang didapat di dalam paket dan produk yang dijual perusahaan Bali Apollo Dive \& Water Sport sehingga wisatawan tertarik untuk berkunjung dan memakai jasa Bali Apollo Dive \& Water Sport.

2. Harga (Price)

Analisis harga dalam penelitian menganalisa mengenai harga paket dan produk yang ditawarkan oleh perusahaan Bali Apollo Dive \& Water Sport terjangkau dan sesuai dengan kualitas jasa dan produk yang ditawarkan.

3. Promosi (Promotion)

Analisis Promosi dalam penelitian ini adalah meneliti mengenai promosi yang digunakan di Bali Apollo Dive \& Water Sport dalam personal selling (mengenalkan produk secara langsung atau media cetak seperti brosur ) dan mass selling ( mengenalkan produk melalui media online )

4. Saluran Distribusi (Place)

Analisis distribusi dalam penelitian ini adalah analisis lokasi Bali Apollo Dive \& Water Sport dan kondisi akses dan transportasi yang bisa digunakan dalam menuju lokasi Bali Apollo Dive \& Water Sport.

5. Personal (People)

Personal yang dimaksud dalam penelitian ini adalah pelayanan yang diberikan oleh perusahaan Bali Apollo Dive \& Water Sport kepada wisatawan pada saat berkunjung.

6. Bentuk Fisik (Physical Evidence)

Bentuk fisik adalah lingkungan internal perusahaan dan merupakan bukti nyata yang dapat dilihat oleh wisatawan seperti tempat parkir yang memadai, dan kondisi bangunan Bali Apollo Dive \& Water Sport yang bersih dan menarik serta seragam pegawai Bali Apollo Dive \& Water Sport.

7. Proses (Process)

Proses yang dimaksud dalam penelitian ini adalah proses pengemasan dan penyampaian informasi jasa yang baik dan jelas sehinggam wisatawan mengetahui jadwal, mekanisme, aktivitas serta fasilitas dalam sebuah paket dan produk Bali Apollo Dive \& Water Sport.

\section{Faktor Eksternal}

Faktor eksternal yang dimaksud dalam penelitian ini adalah berbagai peluang yang dapat menguntungkan Bali Apollo Dive \& Water Sport dan berbagai ancaman yang harus dihindari oleh Bali Apollo Dive \& Water Sport yang dilihat dari faktor luar dari Bali Apollo Dive \& Water Sport. Faktor-faktor yang dimaksud, yaitu:

1. Analisis Pesaing

Analisis Pesaing yang dimaksud dalam penelitian ini adalah banyaknya perusahaan water sport serta kemajuan media yang digunakan dalam melayani wisatawan yang berkunjung.

2. Analisis Alam

Analisis Alam yang dimaksud dalam penelitian berkaitan dengan kondisi lingkungan dan bencana alam yang mempengaruhi tingkat kunjungan wisatawan.

3. Analisis Politik

Analisis Politik yang dimaksud dalam penelitian ini adalah keterlibatan dan dukungan dari pemerintah dalam mengembangkan dan pembangunan infrastruktur yang menunjang pariwisata serta menjamin keamanan yang ada di daerah pariwisata tersebut.

4. Analisis Teknologi

Analisis teknologi yang dimaksud dalam penelitian ini adalah pemanfaat kemajuan teknologi sebagai alat untuk memasarkan paket dan produk yang ada di Bali Apollo Dive \& Water Sport.

5. Analisis Ekonomi

Analisis ekonomi yang dimaksud adalah adanya penurunan mata uang rupiah atau krisis ekonomi yang berpengaruh pada daya beli masyarakat.

6. Analisis Sosial Budaya

Analisis sosial budaya yang dimaksud adalah interaksi yang baik antara wisatawan dengan pegawai Bali Apollo Dive \& Water Sport yang berpengaruh pada minat wisatawan untuk datang ke Bali Apollo Dive \& Water Sport. 
Dalam penelitian ini untuk mengetahui posisi Bali Apollo Dive \& Water Sport dan memperoleh strategi bisnis maka setelah melakukan penilaian terhadap kombinasi faktor internal dan eksternal Bali Apollo Dive \& Water Sport, maka dapat disusun matriks internal eksternal (IE). Dalam analisis tersebut diidentifikasikan menjadi sembilan sel strategi pada Bali Apollo Dive \& Water Sport, tetapi pada prinsipnya kesembilan sel tersebut dikelompokkan menjadi tiga strategi utama. Pertama, growth strategy, merupakan pertumbuhan Bali Apollo Dive \& Water Sport itu sendiri atau upaya diversifikasi. Kedua, stability strategy, merupakan strategi yang diterapkan tanpa mengubah arah strategi yang telah ditetapkan. Dan retrenchement strategy, merupakan usaha memperkecil atau mengurangi usaha yang dilakukan Bali Apollo Dive \& Water Sport.

Data-data yang diperoleh dilapangan melalui analisis ini deskriptif nantinya akan dipadukan dengan teknik SWOT, dimana teknik analisis ini berguna untuk mengetahui tentang kekuatan (Strengths), kelemahan (Weaknesses), peluang (Opportunities), dan ancaman (Threats). Hal ini digambarkan dengan menggunakan matrik SWOT yang menghasilkan 4 set kemungkinan alternatif strategis, yaitu:

1. Strategi SO (Strengths - Opportunities)

Strategi ini dibuat berdasarkan jalan pikiran perusahaan, yaitu memanfaatkan seluruh kekuatan untuk merebut dan memanfaatkan peluang sebesar-besarnya.

2. Strategi ST (Strengths - Threats)

Strategi dalam menggunakan kekuatan yang dimiliki perusahaan untuk mengatasi ancaman.

3. Strategi WO (Weaknesses - Opportunities) Strategi ini diterapkan berdasarkan pemanfaatan peluang yang ada dengan cara meminimalkan kelemahan yang ada.

4. Strategi WT (Weaknesses - Threats)

Strategi ini didasarkan pada kegiatan yang bersifat defensive atau bertahan dan berusaha meminimalkan kelemahan yang ada serta menghindari ancaman.

Analisis SWOT adalah mengidentifikasi berbagai faktor secara sistematis untuk merumuskan strategi dan didasarkan pada logika yang dapat memaksimalkan kekuatan (strengths) dan peluang (opportunities) namun secara bersamaan dapat meminimalkan kelemahan (weakness) dan ancaman (threats).

\section{HASIL DAN PEMBAHASAN \\ Gambaran Umum}

Bali Apollo Dive \& Water Sport merupakan adalah perusahaan yang tetap aktif dan berkembang sampai saat ini. Bali Apollo Dive \& Water Sport, merupakan salah satu perusahaan pariwisata di bidang wisata bahari yang menawarkan jasa olah raga air yang terletak di Tanjung Benoa Bali. Bali Apollo Dive \& Water Sport memiliki banyak inovasi perihal paket wisata dan memiliki fasilitas yang sangat sangat lengkap dibandingkan perusahaan watersport lainnya yang ada di Tanjung Benoa, yang membuat perusahaan Bali Apollo Dive \& Water sport tetap bertahan dan dikenal oleh wisatawan.

Berbekal pengalaman kerja di salah satu usaha watersport yang ada di Bali, pada bulan 23 Februatri 2000, para pemegang saham PT.Bali Apollo bertekad mendirikan sebuah usaha watersport yang diberi nama PT. Bali Apollo Dive \& Watersport yang beralamat di Jl. Pratama 70 Tanjung Benoa, Nusa Dua, Bali, dan sesuai keputusan Gubernur Bali mengenai SIUP (Surat izin Usaha Perdagangan) Nomor 556.1/163/Disparda. PT. Bali Apollo Dive \& Water Sport bergerak dibidang jasa pelayanan wisata bahari dari standar operasional seperti: kantor induk, restaurant, ruang administrasi, ruang ganti, toilet, shower, locker, class room untuk dive Course, lahan parkir, perlatan wahana bermain, dan transport darat untuk mendukung pick up service. PT. Bali Apollo Dive \& Wate Sport mempekerjakan lebih dari 70 orang karyawan termasuk di bagian laut dan kantor.

\section{Karakteristik Wisatawan}

Karakteristik wisatawan yang menggunakan jasa Bali Apollo Dive \& Water Sport dalam paket wisata water sport seperti kewarganegaraan, jenis kelamin, umur, pekerjaan, pendidikan, darimana wisatawan mengetahui Bali Apollo Dive \& Water Sport, darimana wisatawan mengetahui paket water sport yang dimiliki Bali Apollo Dive \& Water Sport, berapa kali wisatawan menggunakan jasa yang diberikan oleh Bali Apollo Dive \& Water Sport dan dengan siapa wisatawan 
menggunakan jasa yang disediakan Bali Apollo Dive \& Water Sport.

Wisatawan yang datang berkunjung dan menggunakan jasa Bali Apollo Dive \& Water Sport berdasarkan kewarganegaraan paling banyak yaitu Indonesia sebanyak 150 dengan presentasi $100 \%$. Wisatawan yang berkunjung mayoritas Indonesia dikarenakan adanya virus corona yang menyebar di seluruh dunia sehingga tidak adanya Penerbangan Internasional Bandara I Gusti Ngurah Rai.

Wisatawan yang berkunjung dan menggunakan paket wisata Bali Apollo Dive \& Water Sport jika dari jenis kelamin yaitu Laki Laki Sebanyak 81 dan Perempuan Sebanyak 69, dimana lebih banyak laki laki yang berkunjung dibandingkan perempuan. Jumlah Kunjungan wisata yang datang ke Bali Apollo Dive \& Water Sport mayoritas laki laki dikarenakan water sport merupakan wisata bahari yang termasuk extreme dan lebih banyak diminati oleh laki laki dibandingkan perempuan.

Wisatawan yang datang berkunjung dan menggunakan jasa Bali Apollo Dive \& Water Sport berdasarkan kewarganegaraan paling banyak yaitu Indonesia sebanyak 150 dengan presentasi $100 \%$. Wisatawan yang berkunjung mayoritas Indonesia dikarenakan adanya virus corona yang menyebar di seluruh dunia sehingga tidak adanya Penerbangan Internasional Bandara I Gusti Ngurah Rai.

Wisatawan yang berkunjung dan menggunakan paket wisata Bali Apollo Dive \& Water Sport jika dari jenis kelamin yaitu Laki Laki Sebanyak 81 dan Perempuan Sebanyak 69, dimana lebih banyak laki laki yang berkunjung dibandingkan perempuan. Jumlah Kunjungan wisata yang datang ke Bali Apollo Dive \& Water Sport mayoritas laki laki dikarenakan water sport merupakan wisata bahari yang termasuk extreme dan lebih banyak diminati oleh laki laki dibandingkan perempuan.

Wisatawan yang berkunjung dan menggunakan jasa Bali Apollo Dive \& Water Sport berdasarkan umur wisatawan adalah wisatawa yang berumur 17 - 30 Tahun dikarenakan water sport merupakan olah raga air yang ekstrem dan disukai oleh kalangan anak muda akan tetapi wisata water sport tidak cocok untuk wisatawan yang mempunyai usia diatas 50 Tahun.
Karakteristik wisatawan yang berkunjung dan membeli paket wisata Bali Apollo Dive \& Water Sport berdasarkan pekerjaannya adalah wisatawan yang memiliki pekerjaan sebagai pegawai swasta, dikarenakan wisatawan yang berkunjung ke Bali Apollo Dive \& Water Sport cenderung memiliki penghasilan yang lebih dan cukup untuk membeli paket wisata Bali Apollo Dive \& Water Sport.

Karakteristik wisatawan yang memakai jasa yang diberikan Bali Apollo Dive \& Water Sport berdasarkan pendidikannya yaitu SMA/Sederajat karena wisatawan yang memakai jasa dan membeli paket Bali Apollo Dive \& Water Sport setelah lulus SMA/Sederajat kemudian berusaha mencari uang sendiri dengan cara bekerja dan sekolah untuk mencapai pendidikan diploma atau sarjana.

Wisatawan yang menggunakan jasa Bali Apollo Dive \& Water Sport berdasarkan darimana mengetahui Bali Apollo Dive \& Water Sport adalah banyak mengetahui melalui teman, dikarenakan banyak wisatawan yang berkunjung mendapatkan informasi melalui teman yang sudah pernah berkunjung dan memakai jasa Bali Apollo Dive \& Water Sport dibandingkan mendapatkan informasi melalui brosur yang ada, travel agent maupun Sosial Media.

Wisatawan yang berkunjung dan menggunakan jasa pelayanan Bali Apollo Dive \& Water Sport berdasarkan karakteristik wisatawan darimana mengetahui paket wisata Bali Apollo Dive \& Water Sport adalah melalui travel agent dikarenakan banyak wisatawan yang berkunjung ke Bali Apollo Dive \& Water Sport dan mengetahui informasi tentang adanya wisata water sport Bali Apollo Dive \& Water Sport melalui temannya. Berdasarkan kusioner banyak wisatawan yang mengetahui adanya Bali Apollo Dive \& Water Sport melalui teman akan tetapi rata-rata wisatawan bertanya tentang paket yang disediakan Bali Apollo Dive \& Water Sport melalui travel agent dikarenakan travel agent lebih mengetahui paket yang disediakan Bali Apollo Dive \& Water Sport.

Wisatawan yang berkunjung dan menggunakan jasa Bali Apollo Dive \& Water Sport berdasarkan berapa kali membeli paket wisata Bali Apollo Dive \& Water Sport adalah pertama kali karena wisatawan yang 
menggunakan jasa Bali Apollo Dive \& Water Sport merupakan wisatawan yang memiliki ketertarikan oleh wisata water sport Bali Apollo Dive \& Water Sport di Tanjung Benoa. Banyaknya informasi tentang water sport Bali Apollo Dive \& Water Sport yang beredar luas dari mulut ke mulut membuat wisatawan semakin tertarik untuk berkunjung dan mencoba membeli paket yang ada di Bali Apollo Dive \& Water Sport.

Wisatawan yang berkunjung dan membeli paket Bali Apollo Dive \& Water Sport berdasarkan dengan siapa menggunakan jasa Bali Apollo Dive \& Water Sport adalah dengan teman. Wisatawan berkunjung ke Bali Apollo Dive \& Water Sport dengan teman karena banyaknya wahana yang disediakan oleh Bali Apollo Dive \& Water Sport yang dapat dikatakan ekstrem dan lebih seru bila dilakukan dengan teman dibandingkan sendiri.

\section{Kondisi Lingkungan Internal}

Dalam menilai kondisi lingkungan internal paket wisata water sport Bali Apollo Dive \& Water Sport diperlukan variabel dan indikator dari bauran pemasaran (marketing mix) yaitu 7P yang mencangkup Produk (Product), Harga (Price), Saluran Distribusi (Place), Promosi (Promotion), Personal (People), Bukti Fisik (Physical Evidence) dan Proses (Process). Hasil dari penyebaran kuesioner yang telah diisi oleh 150 orang wisatawan atau responden yang membeli paket wisata water sport Bali Apollo Dive \& Water Sport adalah untuk mengetahui kekuatan dan kelemahan dari lingkungan internal Bali Apollo Dive \& Water Sport. Berdasarkan hasil penghitungan kuesioner yang telah disebarkan, maka diperoleh kekuatan dan kelamahan paket wisata water sport di Bali Apollo Dive \& Water Sport, yang menunjukkan bahwa hasil penelitian mengenai faktor lingkungan internal di Bali Apollo Dive \& Wate Sport yang diperoleh dari hasil penyebaran kuesioner kepada wisatawan yang berkunjung dan membeli paket wisata water sport di Bali Apollo Dive \& Water Sport. Penelitian ini menggunakan 18 indikator lingkungan internal. Dari hasil penelitian tersebut terdapat 17 indikator dimana ada 14 indikator yang menjadi kekuatan dan 3 indikator yang menjadi kelemahan.

\section{Kondisi Lingkungan Eksternal}

Pemasaran lingkungan eksternal Bali Apollo Dive \& Water Sport yang dimaksud adalah segala kejadian yang ada diluar lingkungan Bali Apollo Dive \& Water Sport yang berpontensi menjadi peluang dan ancaman untuk Bali Apollo Dive \& Water Sport. Peluang dan ancaman tersebut akan menjadi acuan yang nantinya akan digunakan Bali Apollo Dive \& Water Sport untuk dapat menyesuaikan strategi yang diterapkan agar mempu bertahan. Hasil dari penyebaran kuesioner yang telah diisi oleh 10 orang karyawan Bali Apollo Dive \& Water Sport. Berdasarkan hasil penghitungan kuesioner lingkungan eksternal yang telah disebarkan, maka diperoleh peluang dan ancaman pada paket wisata water sport pada Bali Apollo Dive \& Water Sport. Berdasarkan hasil penelitian faktor eksternal yang didapat dari penyebaran kusioner kepada 10 karyawan Bali Apollo Dive \& Water Sport. Penelitian ini menggunakan 11 indikator lingkungan eksternal. Dari penyebaran kusioner tersebut terdapat 9 indikator yang menjadi peluang dan 2 indikator yang menjadi ancaman.

\section{Bobot Rating dan Skor}

Strategi pemasaran yang dapat dilakukan oleh Bali Apollo Dive \& Water Sport dalam memasarkan paket wisata watersport adalah dengan menganalisis terlebih dahulu faktor lingkungan internal (Internal Factor Analysis Summary) IFAS sehingga dapat diketahui total dari masing-masing faktor internal dengan menghitung rating, bobot dan skor dari hasil kuesioner yang dibagikan kepada 5 orang Akademisi Pariwisata yang berkompeten di bidang pemasaran dan menganalisis faktor lingkungan eksternal (External Factor Analysis Summary) EFAS sehingga dapat diketahui total dari masing-masing faktor eksternal dengan menghitung rating, bobot dan skor dari hasil kuesioner yang juga dibagikan kepada 5 orang Akademisi Pariwisata yang berkompeten di bidang pemasaran. Berdasarkan hasil penelitian dapat diketahui hasil dari pengolahan data Bobot, Rating dan Skor (Bobot x Rating) lingkungan internal paket wisata water sport pada Bali Apollo Dive \& Water Sport, dapat diketahui bahwa total internal Bali Apollo Dive \& Water Sport adalah 1,00 dengan jumlah Skor adalah 3,17 . Berdasarkan hasil dari pengolahan 
data Bobot, Rating dan Skor (Bobot x Rating) lingkungan eksternal paket wisata water sport Bali Apollo Dive \& Water Sport, dapat diketahui bahwa total eksternal Bali Apollo Dive \& Water Sport adalah 1,00 dengan jumlah Skor 2,31.

\section{Penentuan Matriks Internal Eksternal}

Berdasarkan hasil yang diperoleh dari matriks IFAS dan matriks EFAS Bali Apollo Dive \& Water Sport maka selanjutnya dapat disusun dalam matriks internal eksternal (IE). Matriks internal dan eksternal (IE) digunakan untuk menganalisis posisi perusahaan secara lebih detail dan melihat strategi apa yang tepat untuk diterapkan oleh perusahaan. Berdasarkan hasil pengolahan data, dapat diperoleh hasil dari nilai total IFAS sebesar 3,17 dan nilai total EFAS sebesar 2,31 menunjukkan posisi paket wisata water sport pad Bali Apollo Dive \& Water yang berada pada sel VIII. Pada posisi ini adalah Growth dan Diversifikasi Konglomerat. Dalam strategi ini, Bali Apollo Dive \& Water Sport dalam memasarkan paket wisata water sport Bali Apollo Dive \& Water Sport memerlukan strategi pertumbuhan melalui tekanan strategi yaitu lebih ditekankan pada sinergi finansial daripada sinergi pemasaran produk.

\section{Analisis SWOT}

Analisis SWOT merupakan metode yang digunakan untuk menganalisis paket wisata watersport berdasarkan faktor internal yaitu sebagai Kekuatan (Strengths) dan Kelemahan (Weaknesses), serta faktor eksternal yaitu sebagai Peluang (Opportunities) dan Ancaman (Threats) yang diperoleh dari hasil penelitian pada Bali Apollo Dive \& Water Sport. Berdasarkan analisis SWOT ditemukan strategi dan program pemasaran yang dapat diterapkan oleh Bali Apollo Dive \& Water Sport. Berdasarkan hasil penelitian pada faktor internal dan eksternal, maka dapat disusun strategi pemasaran yang bisa digunakan oleh Bali Apollo Dive \& Water Sport. Strategi tersebut diperoleh dari hasil analisis dan penyebaran kusioner pada lingkungan internal dan eksternal di Bali Apollo Dive \& Water Sport. Adapun beberapa strategi pemasaran yang dapat dirumuskan dalam memasarkan paket wisata watersport di Bali Apollo Dive \& Water Sport sebagai berikut.

\section{Strategi Menerapkan Sistem Peluang Usaha Berbasis Online}

Strategi menerapkan sistem peluang usaha berbasis online penting dilakukan oleh Bali Apollo Dive \& Water Sport demi keberlangsungan usaha atau bisnis yang dijalani. Adapun program yang dapat diterapkan, antara lain:

1. Memulai membuat system berbasis website yang lebih menarik lagi untuk mejual paket wisata watersport Bali Apollo Dive \& Water Sport kepada wisatawan yang berada di luar Bali.

2. Memadukan antara system berbasis website dengan system pembayaran yang lebih mudah agar wisatawan mudah memesan paket wisata Bali Apollo Dive \& Water Sport dan memudahkan Bali Apollo Dive \& Water Sport Menjual paket wisata kepada wisatawan.

\section{Strategi Meningkatkan Kerjasama dan Meningkatkan Promosi Melalui Media Cetak dan Media Internet}

Strategi Meningkatkan kerjasama antara perusahaan Bali Apollo Dive \& Water Sport dengan perusahaan pariwisata lainnya serta meningkatkan promosi melalui media cetak dan media internet untuk memperkenalkan paket wisata watersport kepada perusahaan pariwisata lainnya seperti travel agent dan hotel yang ada di sekitar Tanjung Benoa. Program yang dapat diterapkan yaitu:

1. Kerjasama dengan pelaku usaha pariwisata lainnya seperti travel agent dan hotel yang ada di Bali guna memudahkan dalam memudahkan menjual paket wisata Bali Apollo Dive \& Water Sport serta dapat menguntungkan kedua belah pihak perusahaan.

2. Meningkatkan promosi paket wisata watersport dengan cara bekerjasama dengan penyiaran TV dan Radio swasta untuk mempromosikan paket wisata watersport yang dipasarkan Bali Apollo Dive \& Water Sport. Meningkatnya promosi dan kerjasama dengan penyiaran TV dan Radio swasta diharapkan dapat menjangkau dan mendatangkan wisatawan lebih banyak lagi. 


\section{Strategi Meningkatkan System Penjualan Paket Wisata Melalui Media Internet}

Strategi pengembangan promosi penting dilakukan untuk memperkenalkan dan memasarkan paket watersport yang ada. Adapun program yang dapat diterapkan, antara lain:

1. Mulai membangun kepercayaan dengan menulis sebuah blog dengan menyajikan informasi yang berkaitan dengan aktifitas watersport Bali Apollo Dive \& Water Sport serta mempromosikan dan mencantumkan website Bali Apollo Dive \& Water Sport kedalam artiket didalam blog tersebut. Blog tersebut dibuat semenarik mungkin agar kualitas konten yang digunaka menarik wisatawan membaca isi blog tersebut dan memesan paket wisata watersport Bali Apollo Dive \& Water Sport.

2. Memanfaatkan kemajuan IPTEK dan variasi paket wisata yang ada serta meberikan artikel kedalam sosial media mengenai produk wisata watersport yang banyak diminati wisatawan sehingga bisa menarik wisatawan melalui sosial media seperti Facebook, Instagram, dan Website.

3. Memberikan informasi didalem media social tentang situasi terkini didalam media social yang ada di Bali Apollo Dive \& Water Sport tentang situasi yang terdapat di lokasi Bali Apollo Dive \& Water Sport dan karyawan yang telah divaksinasi dan dipastikan aman dan bebas dari Virus Corona atau Covid-19.

\section{Strategi Pengembangan Promosi Paket Wisata}

Strategi pengembangan promosi penting dilakukan bagk perusahaan untuk memperkenalkan dan memasarkan paket wisata watersport yang ada di Bali Apollo Dive \& Water Sport kepada wisatawan. Adapun program yang dapat diterapkan oleh Bali Apollo Dive \& Water Sort yaitu:

1. Peningkatan promosi paket wisata watersport yang disediakan Bali Apollo Dive \& Water Sport pada sosial media yang dimiliki Bali Apollo Dive \& Water Sport dengan cara melakukan promosi paket wisata watersport pada Bali Apollo Dive \& Water Sport secara berkala melalui akun facebook, instagram dan sebagainya yang berisikan mengenai kejelasan paket wisata watersport dengan lebih detail dengan penawaran harga yang ditawarkan sehingga diharapkan dapat membuat wisatawan mengetahui detail paket wisata watersport yang disediakan oleh Bali Apollo Dive \& Water Sport.

2. Pengembangan penyajian dalam bentuk brosur agar lebih menarik lagi. Pengembangan brosur dibuat lebih menarik agar brosur yang dibuat oleh Bali Apollo Dive \& Water Sport dapat menarik minat wisatawan untuk melihat brosur tersebut. Brosur yang menarik dapat mempromosikan perusahaan dengan cara menaruh dan membagikan brosur tersebut kepada wisatawan maupun perusahaan yang menjadi partner Bali Apollo Dive \& Water Sport.

3. Memberikan tambahan didalam paket wisata yang membuat wisatawan tertarik seperti, free Rapid Test Antigen dan memberikan beberapa souvenir seperti masker dan sarung tangan yang berguna bagi wisatawan dimasa pandemic.

\section{SIMPULAN DAN SARAN \\ Simpulan}

Berdasarkan latar belakang dan pembahasan yang dipaparkan diatas, maka dapat disimpulkan sebagai berikut:

1. Indikator-indikator internal yang menjadi kekuatan dari Bali Apollo Dive \& Water Sport dalam memasarkan paket wisata watersport adalah (1) Variasi paket wisata yang dijual Bali Apollo Dive \& Water Sport (2) Harga paket wisata yang ada di Bali Apollo Dive \& Water Sport (3) Lokasi Bali Apollo Dive \& Water Sport (4) Akses menuju Bali Apollo Dive \& Water Sport (5) Transportasi yang bisa digunakan menuju Bali Apollo Dive \& Water Sport (6) Pelayanan kepada wisatawan saat wisatawan melakukan aktifitas watersport (diving, jet ski, banana boat, dll) (7) Keramahan pegawai kepada wisatawan yang berkunjung (8) Kesopanan pegawai kepada wisatawan yang berkunjung (9) kemampuan pegawai dalam berbahasa (inggris atau Indonesia) sangat baik (10) Kerapian Seragam karyawan Bali Apollo Dive \& Water Sport (11) Perlengkapan keselamatan yang disediakan di Bali Apollo Dive \& Water Sport seperti P3K, 
life jacket (12) Perlengkapan fasilitas Aktifitas Water Sport (Banana boat, jet ski, diving, dll) sesuai standar (13) Proses transaksi yang aman dan mudah (14) Proses Pemesanan paket wisata Bali Apollo Dive \& Water Sport. Sedangkan indikatorindikator yang menjadi kelemahan Bali Apollo Dive \& Water Sport dalam memasarkan paket wisata watersport yaitu (1) Penyajian paket wisata dalam bentuk brosur (2) Promosi paket wisata Bali Apollo Dive \& Water Sport melalui media internet (3) Promosi paket wisata Bali Apollo Dive \& Watersport melalui media cetak seperti brosur.

2. Indikator-indikator eksternal yang menjadi peluang bagi Bali Apollo Dive \& Water Sport dalam memasarkan paket wisata watersport adalah (1) Adanya Kerjasama antar perusahaan watersport dan perusahaan pariwisata lainnya dalam pemasaran paket wisata Bali Apollo Dive \& Water Sport (2) Kondisi Lokasi disekitar Bali Apollo Dive \& Water Sport (3) Dukungan pemerintah setempat (4) Kondusifnya keamanan di Bali (5) Pemanfaatan kemajuan teknologi yang modern dalam memasarkan paket wisata Bali Apollo Dive \& Watersport (6) Nilai Tukar mata uang rupiah yang berpengaruh pada daya beli wisatawan (7) Perilaku masyarakat sekitar yang mendukung adanya kegiatan wisata di sekitar Tanjung Benoa (8) Semakin banyaknya pesaing perusahaan water sport yang ada di daerah Tanjung Benoa. Sedangkan indikatorindikator yang menjadi ancaman Bali Apollo Dive \& Water Sport dalam memasarkan paket wisata watersport adalah (1) Tingkat Bencana Alam di Bali (2) Adanya Virus yang ada di Bali (3) Kecanggihan media yang digunakan perusahaan water sport lainnya.

3. Strategi dan program pemasaran yang dapat diimplementasikan oleh Bali Apollo Dive \& Water Sport dalam memasarkan paket wisata watersport adalah (1) Strategi menerapkan system peluang usaha (2) Strategi meningkatkan kerjasama dan meningkatkan promosi melalui cetak dan media internet (3) Strategi meningkatkan system penjualan paket wisata melalui media Internet (4) Strategi pengembangan promosi.

\section{Saran}

Berdasarkan simpulan diatas, maka saran yang dapat diberikan kepada Bali Apollo Dive \& Water Sport, sebagai berikut.

1. Bali Apollo Dive \& Water Sport harus meningkatkan promosi paket wisata watersport yang ada pada media social maupun media cetak agar paket wisata yang dimiliki oleh Bali Apollo Dive \& Water Sport lebih dikenal oleh wisatawan.

2. Bali Apollo Dive \& Water Sport harus memiliki social media seperti Facebook, instagram yang aktif dan memiliki beberapa foto dokumentasi yang menarik. Selain memiliki dokumentasi foto yang menarik di sossial media Bali Apollo Dive \& Water Sport juga harus memiliki informasi yang jelas perihal letak lokasi dan daftar paket wisata watersport yang dimiliki oleh Bali Apollo Dive \& Water Sport.

3. Bali Apollo Dive \& Water Sport harus memiliki website yang menarik dan mudah digunakan oleh wisatawan maupun travel agent yang ingin memesan paket wisata watersport Bali Apollo Dive \& Water Sport.

4. Bali Apollo Dive \& Water Sport harus menjalin kerjasama dengan online travel agent lain dalam membantu penjualan paket wisata watersport.

5. Bali Apollo memiliki paket promosi untuk menarik wisatawan untuk berkunjung dimusim pandemi.

6. Memiliki promosi yang berkaitan dengan pandemi seperti rapid, masker dam paket promosi.

7. Lebih meningkatkan lagi promosi tentang watersport safety untuk digunakan dalam musim pandemi. 


\section{Kepustakaan}

Kotler dan Keller, 2007. Manajemen Pemasaran, Edisi 12, Jilid1, PT. Indeks, Jakarta.

Kotler, Amstrong. 2001. Prinsip-prinsip Pemasaran, Edisi keduabelas, Jilid 1. Jakarta: Erlangga.

Kusmayadi dan Endar Sugiarto. 2000. Metodologi Penelitian dalam Bidang Kepariwisataan. Jakarta: PT. Gramedia Pustaka Utama.

Kusmayadi dan Sugiarto, 2000.Data Kuantitatif. Jakarta: Balai Pustaka.

Lupiyoadi, Rambat. 2001. Manajemen Pemasaran Jasa. Jakarta: PT. Selemba Embat Patria.

Nazir, 2005. Studi Kepustakaan. Yogyakarta: Andi.

Philip Kotler, 1997, Manajemen Pemasaran Analisis Perencanaan Implementasi dan Koneral, Jilid I, Penerbit PT Prenhallindo, Jakarta.

Rangkuti, Freddy. 2002. Analisis SWOT Teknik Membedah Kasus Bisnis. Jakarta: Gramedia Pustaka Utama.

Sugiyono. 2007. Metode Penelitian Kuantitatif, Kualitatif dan Research and Design. Bandung: Alfabeta.

Tjiptono, Fandy. 2002. Strategi Pemasaran. Yogyakarta: Penerbit Andi. 